\title{
The Dramaturgy and the Amateur Arberesh Theater
}

\author{
Dr. Meli Shopi \\ Universiteti “Aleksander Xhuvani”, Elbasan \\ Email:melishopi@yahoo.it \\ Msc. Denis Himci \\ Universiteti "Aleksander Xhuvani”, Elbasan \\ Email:denis_himci@hotmail.com
}

\section{Doi:10.5901/ajis.2013.v2n8p204}

\begin{abstract}
In the framework of the artistic literary creativity of the Arbëresh of Italy, after a relatively long period of silence during the last decades, nowadays it can be noticed a revival of the creative activity of arbëresh poets and writers. Once, in the Arbëresh environments poetry has been more developed, but also Albanian drama originated there, but if we consider that "Emira" of AF Santori actually marked the beginnings of dramaturgy in Albanian. The development of Arbëresh poetry havs been favored by the circumstances connected to the idea that there have always been poets there. However, it should be mentioned that in terms of diversity, Arbëresh literature has never been richer than today. To the volumes of poetry are added further dramatic creations, especially by the comedies of Di Maxhios, the Dushko Vetmos etc., but there is also a development of the short prose. This paper deals with the richness and the linguistic and literary features of the dramatic works of the Arbëresh ,by considering it as a developing genre in the literature of the nineteenth century, but now from a different prespective. The simple, communicative language with lexical richness clearly shows the values and its foundation on the tradition and living Arbëresh culture.
\end{abstract}

Keywords: arbëresh comedy in Albanian language, thematic diversity, dramatic genre, Albanian language, literary traditions, ethnocultural values.

One of the most interesting sides of that literary and cultural revival of Italy in our time is certainly also the dramaturgy, as written composition but also as an amateur movement. You know, that on the historical - literary, just in the settlements arberesh Italy is the starting point of the drama as a genre. Anton Francesco Santori with his "Emira" still remains the first playwright of the literature arberesh and overall dramaturgy Albanian. Santori was one of the most productive authors of the arberesh literature, but unfortunately also one of the most unfortunate; most of his poems, prose and drama, for tens of years have been forgotten, without being published. Lately arberesh scholars have published or are preparing to publish some of the most unknown work by this author. A few years ago, with Karmell Kandreva, it was announced on "Drita" the discovery of a manuscript with the title"Satire, "A work which we later transcribed and we have provided with notes and then we published it (Shkurtaj, 1982). In 1984, on the occasion of the centenary of the death of F.A.Santore, the arberesh scholar Francis Solano has published its entire work "Ermira." Also adding acts that were not known before. (Solano, 1984) "Ermira" is, therefore, the first drama known in the Albanian language."

Another dramatic work also unknown lately is "Aleks Dukagjini" which has been found and provided with notes by Professor Francis Solano and was published in the series "The Fire". With "Aleks Dukagjini" the figure of Santore as a playwright acquires new dimensions and values. This is an opera in four acts with a person in the period of Skenderbe. At the center there is a known conflict between Aleks Dukagjini and Zaharia Gropa because of the beautiful Jerina. The author has been able to paint the character of the main representative personages $s$ of two known Albanians ports and acquired an interesting dramatic atmosphere.

If F.A.Santore, as the first Albanian playwright but also as the first author arberesh and also the author of the first Albanian-language drama has the merit of the precedence in this genre, the circumstances known to the arberesh diasporas, among his plays and those that were written after the arberesh authors, it has come to create a great time interruption, a distance that cannot be not taken into consider. Indeed, in the arberesh drama of nowadays, the influence of Santore is neither sensitive nor direct. 
Many of the contemporaries of F. A. Santore as you know, are dedicated to poetry and have not come close to the drama; perhaps also the fact that at that time they did not see in those environments no real possibility for the development of an artistic life and even conditions to build a theater, even amateur. This, perhaps, for reasons that poetry, being more spontaneous but also more binding for authors had more chance of being published. However, it remains the fact that the drama would start arberesh generations in the santoriana direction only in the last thirty years. The principal authors are three: Dushko Vetmo in Frasnite (Calabria) with only two plays, mainly the type of "Lesedramma" (= a drama just to read): "And even the moon"and"The stone desert". The second, Zef del Gaudio (Giuseppe del Gaudio) Shen - Koll from parts of Cattanzaro with a series of dramas mainly with the theme of the history of Albania and the establishment of arberesh in Italy. We can mention among other things, the trilogy of Skenderbe "The marriage of Jaceria" consists of three parts: "The return of the brave", "The bleeding marriage" and "Moses of Dibra." Part of an another trilogy, not yet completed, are also the dramas "Axhiselao Milan" and "Zef Serembre", which were disclosed in the ranks of arberesh readers and beyond. Let's focus on the most accurate data on the drama "Axhiselao Milan", whose stories, as you also know the name of the hero, take place in the period of the Kingdom of the Bourbons.

The protagonists are: the known arberesh, the valiant Axhiselao Milano and his arberesh compatriots Shen Benedikt, Shen - Miter Korones, Spixanes etc, men and women who are fighting against the tyrannies. In a paper on this work of Del Gaudio, Paskal Renda writes: "Choosing the work (= reading) the drama so many ideas come to mind: the bad luck that you will act around people, against the poor, against those who are thirst for freedom and who are convinced that you cannot live without freedom, against the people who cannot stand violence and injustice of the tyrant. And Axhiselao? A hero who has the courage to raise his hand against the king, a guy who has the in the veins hot Albanian blood, of honor struggling with all his might and who gives his life for freedom and falling like a hero to win the tyrannies (Renda).

The last act of the drama reminds us, in some way, the farce known Italian Sako and Vanseti: situations change but the injustice is always the same.... The drama is an apotheosis of arberesh heroism. We also see how they fight and how willing to unsay women also arberesh are. In the embodiment of Madalena and Hareza there is represented the arberesh woman that unlike the women of southern Italy, in the front part of the war, in the revolt and this makes him because inside his chest emerge feeling of freedom. With so much strength and masculinity stands out is the mother of Axhiselau, his internal conflict, "she says at the beginning not to hurry since it was not yet time to war, so she asks her son and his friend's patience and sapience. She does this, not because she feels it, but as a mother, because she fears not only for her husband but also for her son. On the other hand she resists, until the time comes that there is no longer: she oppose to tyrannies.

Her words are: "How can you continue to live in his modest, suspects, without peace in the family and under control day and night .... for them (= then) we are anarchists, foreign, nests of snakes in our homes, hungry wolves arberesh students and their professors masters of hate.

The play ends with very significant words and suitable not only to characterize the inner world of Axhiselau but also with values always present and that touch the hearts of all democrats in every time and place "Freedom is not offering or buying, but deals (= you earn it) just struggling. This is the message of this drama, which, if it will ever staged, surely it would be discovered even with much weight power and influence. The third Zef Skiro Maji (Giuseppe Schiro May) that acts and works at the Arberesh Hora (Piana degli Arberesh) in Sicily, is undoubtedly the best known name in the field of dramaturgy arberesh today.

Much of the works of Di Maggio are now known even among us: in the past, in addition to the poems published in anthologies "The strong roots " (Ismajli, 1978) and "Green Branch" (Jorgaqi, 1998) was also published in the collection with poems selected by him "Beyond the mountain behind the hill "instead of the theater" A.Z.Cajupi "of Korca had staged the comedy" The Wedding ", the subject of which, later, were also booklets of works for the Theatre of Opera and Dance with the music of N.Zoraqi . Meanwhile, it must be said that Zef Skiro Maji is not only a poet and play righter. He is distinguished by the two other authors mentioned above for the reason that while they (Dushko Vetmo and Del Gaudio) wrote only dramas, at the same time he was the director and organizer of an amateur arberesh theater, the first of its kind in the Albanian diasporas. The center of the theater is the Hora or Piana degli Albanesi, a place with about 7000 inhabitants, mainly arberesh who speak Albanian and strongly related to the language and Albanian traditions.

The activity of Di Maggio as a playwright in growth was due (in operation) in this amateur theater and activity of the Cultural Society "Albanian World", established and directed by him for more than fifteen years. From 1982 he wrote and staged about twelve plays, all with the theme of life in his village of Piana of Albanian: "Magic Love " (1982), "The Robe" (1982), "The Wedding" (1983), "The Cider 1860" (1984), "Many visits" (1986), "Buonaora" (1988), "On noble land of Hora "(1989)," Investment in the South "(1990)," Learn the art "(1992)," Other kinds "(1992)," Researchers "(1994). 
After "The Wedding", which was one of his early comedies made up in the scene with amateur actors of the Plain, he has staged and has successfully represented (in Hora and in other arberesh establishments of Sicily and Calabria) most comedies he wrote that we mentioned before. In particular, were seen "The Cider 1860", "Buonaora", "Many visits," "Magic love".

Let us pause a bit in a short presentation of the main ideas that form the basis of the plays by this author. May is known as a poet with trends of humor and satire. His creations, in general, are affected by the current situation, the lives of today's arberesh, giving priority to the expression of identity and of the virtues of this diaspora.

Through a cute humor, irony and involving satire he hits and denies, first, those parts that stops him, in being clearly arberesh. So he wants to express and spend more fury to the preservation of traditions, rituals and the Albanian language as the clearest indicators and ethnic of Albanians in a foreign land. This tendency of satire is spread over in his dramatic works, as in, "Magic love", "The robe", "Many visits "and especially" Buonaora".

He thinks that these "modern times" are ruining the people, are doing to become like the sons of the old Stefan, the protagonist of" The robe "who want to take his wealth, while others are not feelings towards him. "Their parent is only their dresses, I have only the name".

"Ah, this modern life"- says Stefan neighbor. "Before the children honored their parents. And we, arberesh, had always them in the heart. But today, in these times. We see that the feelings have changed. "However, the author draws the lesson that the parents are always warmhearted; it knows neither anger nor hate to his son. The old Stefan divides his entire robe (= richness) to his hereditary soon occur uncaring towards the fate of his father. The old man spends his days in the old nursery, away from his children, who flattered only to have his richness and to ensure their lives only. Here ends the play and each dialogue and said assumed a tone of unmasking satire.

"Many visits" is one of the works in which, as already noted, the criticism arberesh, Di Maggio has taken an important qualitative step. The action here becomes thicker, the dialogue is weighed and relevance valid and in accordance with the Pirandello subject. The drama makes you think, but also make you relive, and also suffer. The drama is set as always in Piana degli Arberesh: two families' lives (resides) in the same house, one of them is from this world, but the other is from the world of the spirits. Who sees the other family? The boy represents people who find themselves in difficult situations and who are looking for reasons to give meaning to life. The other brother "the beautiful" and the sister, representing the youth of today. At the end the sick boy heals and the comedy, as it is usual for the genre, ends so cheerful.

Another work is well received by the audience arberesh "The cider in 1860." It is located in the Plain of Arberesh as always, but in the time of Garibaldi, just when he landed in Sicily and the patriotic forces arberesh helped him to organize a revolt against the Bourbons. Certainly one of the plays most affected of Di Maggio is "Buonaora" written on the occasion of the 500th anniversary of the establishment of Piana degli Arberesh. The scenes of "Buonaora" belong to the last years and to the very period when immigration of arberesh increased in the west of European countries and America, especially to Germany. In the house of Masi Muzaka, a retired worker, an important event happens: suddenly all his three children (Jakini, Poles and Marku) decide to immigrate to Germany, since they could not find work in the Plains. Without overwhelm the contrast between the father and the mother's tears, (Vo Menes) the boys leave, with the faith and the promise that they would return as soon as they had at their disposal a bit of money. The first takes with him his pregnant wife, while the latter, Poles, leaves his beloved with the promise that he would return and they would be married to the Plain. But life in Germany, wanting and not wanting, involving into its vortex arberesh the three boys, their acquired behavior, mentality and German culture. Since Muzaka Masi and his wife, as typical representatives of the traditional life arberesh and how conservative devotees of the Albanian language, traditions and virtues remote with which generation after generation had grown up in the Plains, smell the evil that was approaching. Muzaka is fully convinced that "the fate of arberesh that emmigra twice is heavier than the other "so for this he begs the children not to leave, but to stay in the village with what they had."When someone is forced to leave the plain, I am reminded of when our fathers left Albania; think of the pain of those who leave their home with their people.... tha the elderly parent, who his mother, who, a few younger brother .... that he could not go along with them. And then came here with the idea of returning one day ... But then again their children were born to them and the suffering of their grandparents became nostalgia and mewmories.... always feeling that arberesh were here, some more than others .... But you go now in Germany! The pain is still larger..."

Vo Mena, when she sees that his three sons are leaving for Germany, hastens to give it an arberesh buonaora (= pendant), in which he also put a bit of the plain, with the hope that "with that in the neck would not forget the Plains and the native language ...."But she was very disappointed when after four years; the children that visited the Piana are completely changed: the eldest, Jakin, became a father, but instead that the mother was filled with joy feels like poisoned since he does not have taught him not an arberesh word; the grandson speaks only German. The second, Pal, forgetting 
his promise to Mara, that he would married here just when he would put a little money aside to build the house etc.., Comes without any shame with a nice little German who looks like her mother MARIA and so it bends to pray. The smallest of the three, changed and influenced too much by foreign culture has brought with it English "boyfriend" with hair that looks like a woman and is regarded as such by all the Plain. The house of Masi Muzaka looks like the Tower of Babel: someone speaks German, some English ... and English with his face as a wash of milk mocks the language and traditions arberesh.

The comedy Estata well designed and the action flows so cute, attractive and scenes full of humor, with dialogue and of those impressive, full of irony and sarcasm heavy on the wounds of the time, such as immigration apex of youth arberesh in other countries, inside or outside Italy. "Germany - says Di Maggio - is regarded as a symbol, because this can also be Palermo, Rome, Milan, Turin, etc. as possible places of internal migration of arberesh. In very significant figure of Masi Muzaka, Di Maggio has created one of his most beautiful, has embodied the arberesh that even after five hundred years from the time of the shift from Albania, feels proud of his origin. Significant are the words that Muzaka tells his son, Pal, in the last scene:

"That pendant that your mother gave you were two of us, your parents and the Plain, that came with you, so you could stay in touch with the traditions that we have had in the past and that we still have today, even if it has been five hundred years, it looks like a game that to you we were arberesh for all these century? You left for work, I know! Here there was no work to date and have passed all these century. But what was the need to change your soul? You could not remain those who you were: calm, honest and arberesh? I do not say that you have become criminals too but now you are honest Germans."

Mazi Muzaka looks at the reality in the eye, without disappointment, without getting lost. He understands that under current conditions of southern Italy, the immigration is an irrepressible process for which he not blame the children who went to Germany, and they would still went to another place to earn a living. Like an arberesh and like how honest person who is asking him to their children not to humiliate the good name of his country, to not try a fake shine of the civilization of modern Europe. "You can be arberesh in Germany, if you live with the hope of returning. But, if those who come into your home will break down you with their "civilization" then you will change... I do not want you to change, and every person has the right to be what it is. But I want you to stay strong, because our civilization is beautiful. When civilization is civilization it must be respected.

The comedy "Buonaora" which is the seventh work of Di Maggio marks a success, a nice gift for the author in his Arberesh Piana degli $500^{\text {th }}$ anniversary of its establishment and its population with arberesh.

\section{References}

Salambrina, E. (1997). "La letterattura arberesh contemporanea", in "Le scuole dell'obbligo per la salvaguardia e la promozione della cultura arberesh". Piana degli arberesh.

Jorgaqi, N. (7.11.1998). "Atti del Congresso Internazionale", Piana degli Albanesi.

Shkurtaj, Gj. (1982). "Poezia e sotme arbereshe", Studime filologjike, nr 2.

Ismajli, R. (1978). "Poezia arbereshe e diteve tona". Prishtine: Rilindja.

Renda, P. "Mondo Albanese".

Solano, F. (1984). "Emira di F.A.Santori", edizione del testo albanese, produzione e note a cura del prof. Francesko Solano. 